\title{
KOMITMEN ORGANISASIONAL SEBAGAI MEDIASI PENGARUH PELATIHAN DAN DISIPLIN KERJA TERHADAP KINERJA PEGAWAI
} (Studi pada Dinas Pendapatan Pengelolaan Keuangan dan Asset Kabupaten Malang)

\author{
Reza Septian Nugraha, Margono Setiawan, Astrid Puspaningrum \\ Jurusan Manajemen, Fakultas Ekonomi dan Bisnis, Universitas Brawijaya Malang \\ Koresponden : Jl. Besar ijen 77C/E-12 Malang 65112
}

\begin{abstract}
The purpose of this study was to determine how big of a role Organizational Commitment as a mediation influence training and work discipline to employee performance at DPPKA Malang. The samples are 205 respondents to the sampling method using proportional random sampling method. The approach in this study is a quantitative approach that is supported by the survey, is explanatory. Testing hypotheses in this research using path analysis. The results showed that the training and work discipline can improve employee performance DPPKA Malang, training and discipline can enhance organizational commitment to DPPKA Malang, and organizational commitment has a role as mediation influence training and ork discipline to employee performance at DPPKA Malang. The findings empirically indicated that in order to increase the commitment and performance of employees, the Department of Finance and Asset Management Revenue (DPPKA) Malang regency need to pay attention to the factors that can influence organizational commitment and performance of employees. Recommendations relating to the results of this research in improving organizational commitment and employee performance, it is recommended leader that has the authority to control and more attention, and to conduct periodic performance evaluations.
\end{abstract}

Keywords: Training, Work Discipline, Organizational Commitment and Employee Performance

\begin{abstract}
Abstrak: Tujuan dari Penelitian ini adalah untuk mengetahui seberapa besar peran dari Komitmen Organisasional sebagai mediasi pengaruh pelatihan dan disiplin kerja terhadap kinerja pegawai pada DPPKA Kabupaten Malang. Sampel yang digunakan sebanyak 205 responden dengan metode pengambilan sampel menggunakan metode proporsional random sampling. Pendekatan dalam penelitian ini adalah pendekatan kuantitatif yang didukung survey, bersifat eksplanatori. Hasil penelitian menunjukan bahwa pelatihan dan disiplin kerja dapat meningkatkan kinerja pegawai DPPKA Kabupaten Malang, Pelatihan dan disiplin kerja dapat meningkatkan komitmen organisasional pada DPPKA Kabupaten Malang, dan komitmen organisasional memiliki peran sebagai mediasi pelatihan dan disiplin kerja terhadap kinerja pegawai pada DPPKA Kabupaten Malang. Temuan secara empiris mengindikasikan bahwa untuk meningkatkan komitmen dan kinerja pegawai, maka Dinas Pendapatan Pengelolaan Keuangan dan Asset Kabupaten Malang perlu memperhatikan faktor-faktor yang dapat mempengaruhi komitmen organisasional dan kinerja pegawai, seperti pelatihan dan disiplin kerja. Rekomendasi berkaitan dengan hasil penelitian ini dalam peningkatan komitmen organisasional dan kinerja pegawai ini, disarankan pihak yang memiliki wewenang untuk melakukan pengawasan dan perhatian yang lebih, serta melakukan evaluasi kinerja pegawai secara berkala.
\end{abstract}

Kata Kunci: Pelatihan, Disiplin Kerja, Komitmen Organisasional, dan Kinerja Pegawai

Dalam lingkungan kerja yang semakin kompetitif, baik lokal maupun global banyak perusahaan maupun organisasi pemerintahan saat ini yang diharapkan untuk mencoba menetapkan strategi yang secara langsung terkait dengan peningkatan kinerja organisasi. 
Organisasi yang menginginkan mempunyai daya saing tinggi di masa depan diharapkan dapat melakukan upaya strategis dengan proses belajar melalui pelatihan. Pelatihan sebagai salah satu upaya untuk meningkatkan SDM dalam organisasi, diharapkan mampu memberikan perubahan dalam keahlian, pengetahuan, sikap, dan perilaku, kearah perilaku kerja yang dikehendaki. Melalui pelatihan, pegawai dapat termotivasi dan membantu mengerjakan pekerjaan yang ada, dapat meningkatkan keseluruhan karir pegawai, dan membantu mengembangkan tanggung jawabnya di masa depan. Kenapa pelatihan dalam hal ini, karena menurut Mondy (2008:210) pelatihan adalah suatu kegiatan yang dirancang untuk memberikan pembelajar mengenai pengetahuan dan ketrampilan yang dibutuhkan oleh setiap pekerja dalam menyelesaikan pekerjaan mereka saat ini. Jadi dalam hal ini pelatihan dapat menunjang kinerja para pegawai dalam sebuah organisasi untuk mencapai tujuannya.

Pelatihan manajemen dalam organisasi tentunya memerlukan pengetahuan dan informasi yang baik berkenaan dengan disiplin kerja dari pegawainya, sehingga adanya disiplin kerja pada pegawai sangat dibutuhkan dan merupakan faktor yang penting, karena tujuan organisasi akan sangat sulit dicapai bila tidak ada disiplin dari setiap pegawainya. Disiplin kerja merupakan faktor penting karena disiplin kerja merupakan faktor yang mencerminkan sikap dan tingkah laku para pegawai organisasi dalam mematuhi norma dan aturan, ini sesuai dengan pendapat Singodimedjo dalam Sutrisno (2012) yang menjelaskan disiplin sebagai sikap kesediaan dan kerelaan sesorang untuk menaati dan mematuhi norma atau peraturan yang berlaku di sekitarnya. Setiap pegawai diharapkan mengerti bahwa dengan adanya disiplin kerja pada diri pegawai, akan mendukung dan memberikan manfaat langsung bagi organisasi maupun pegawai yang bersangkutan.

Keberhasilan organisasi adalah pemenuhan kebutuhan diri untuk selalu meningkatkan kinerja pegawainya, baik melalui pelatihan maupun adanya disiplin kerja yang tinggi, sehingga hal ini dapat memberikan rasa untuk berkomitmen seorang pegawai terhadap organisasi. Keadaan demikian mempunyai pengaruh yang positif terhadap organisasi yang bersangkutan. Pada dasarnya, komitmen merupakan salah satu faktor yang sangat penting yang menentukan kinerja. Karena itu bisa dikatakan komitmen organisasioanl merupakan sesuatu yang menunjukkan bagaimana loyalitas para pegawai dalam membantu organisasi untuk ke arah yang lebih baik, hal ini didukung pendapat Luthans (2006:249) mendefinisikan "komitmen organisasional sebagai sikap yang merekfleksikaan loyalitas pegawai kepada organisasi dan merupakan suatu proses yang berkelanjutan dimana setiap anggota organisasi mencurahkan perhatian mereka terhadap organisasi, keberhasilan organisasi serta kemajuan organisasi".

Seorang pegawai dapat mengerjakan sesuatu pekerjaan dengan baik apabila memiliki kemampuan dan komitmen yang dapat menunjang tumbuhnya organisasi, pegawai yang memiliki komitmen yang tinggi akan menunjukkan kinerja yang baik, karena tidak bisa dipungkiri komitmen merupakan faktor penting dalam menentukan kinerja pegawai. Kinerja pegawai merupakan tindakan yang mempengaruhi seberapa banyak pegawai memberikan kontribusi kepada organisasi. Dalam hal ini, kenapa kinerja pegawai karena dalam fenomena yang terjadi belakangan ini dalam sebuah organisasi, seringnya kinerja pegawai menurun dikarenakan kemungkinan adanya ketidaknyamanan dalam bekerja, gaji atau upah minim, motivasi dan juga ketidak puasaan dalam bekerja. Padahal dalam hal ini kinerja tersebut menunjukkan hasil kerja dan kontribusi yang diberikan oleh pegawai terhadap organisasi.

Salah satu Satuan Kerja Perangkat Daerah (SKPD) pemerintahan kabupaten malang yang memiliki jumlah pegawai besar dan rumitnya proses dalam pengelolaannya merupakan Dinas Pendapatan Pengelolaan Keuangan dan Asset (DPPKA) Kabupaten Malang. Instansi DPPKA Kabupaten Malang mempunyai wewenang untuk mengatur pendapatan maupun pengelolaan keuangan dan asset yang ada di kabupaten malang secara efektif, efisien, dan transparan.

Program pelatihan sendiri pun juga sering dilakukan oleh DPPKA dengan adanya kegiatan BIMTEK (BimbinganTeknis) maupun pembelajaran SIMBADA (Sistem Informasi Manaejemen Barang Daerah), hal ini dilakukan 
untuk menunjang setiap kegiatan yang dilakukan oleh organisasi khususnya dalam meningkatkan kemampuan dan ketrampilan sumber daya manusia yang ada dalam organisasi. Tetapi dalam berjalannya waktu program pelatihan yang diterapkan oleh DPPKA masih belum memberikan hasil yang baik dan masih banyak ditemukan pelanggaran disiplin kerja pegawai mengenai pajak daerah maupun inventaris asset daerah yang sebenarnya telah dijelaskan dalam setiap program pelatihan yang dilakukan. Gambaran pelanggaran displin pegawai ini mencerminkan kurangnya pengawasan dan menunjukkan masih rendahnya kinerja pegawai DPPKA Kabupaten Malang dalam menjalankan tugasnya sesuai dengan ketentuan yang ada. Dengan adanya pelanggaran mengenai disiplin pegawai dan rendahnya kinerja pegawai tersebut, sangat menarik bagi peneliti untuk dilakukan penelitian.

Oleh karena itu, tulisan ini bermaksud melihat penerapan pelatihan, disiplin kerja dan peranan komitmen organisasional dalam memediasi pengaruh pelatihan dan disiplin kerja tersebut dalam peningkatan kinerja pegawai DPPKA Kabupaten Malang. Berdasarkan uraian latar belakang diatas, maka dapat dirumuskan permasalahan dalam penelitian ini secara lebih rinci adalah Apakah pelatihan berpengaruh positif terhadap kinerja pegawai DPPKA Kabupaten Malang, Apakah disiplin kerja berpengaruh positif terhadap kinerja pegawai DPPKA Kabupaten Malang, Apakah pelatihan berpengaruh positif terhadap komitmen organisasional DPPKA Kabupaten Malang, Apakah disiplin kerja berpengaruh positif terhadap komitmen organisasional DPPKA Kabupaten Malang, Apakah komitmen organisasional memediasi pengaruh pelatihan terhadap kinerja pegawai pada DPPKA Kabupaten Malang, dan Apakah komitmen organisasional memediasi pengaruh disiplin kerja terhadap kinerja pegawai pada DPPKA Kabupaten Malang.

\section{METODE}

Sesuai dengan pokok masalah dan tujuan penelitian yang telah dirumuskan, maka jenis penelitian ini adalah explanatory research, Menurut Hasan (2002) penelitian yang bersifat penjelasan ini (explanatory research) adalah penelitian yang dalam proses pengujiannya menggunakan data yang sama, dimana peneliti berusaha menunjukkan suatu hubungan kausal atau sebab akibat antara variabel-variabel dalam penelitian dengan melakukan pengujian hipotesis. Pendekatan yang dipakai dalam penelitian ini adalah pendekatan kuantitatif dengan melakukan penelitian yang berkaitan pada survei, dan sampel penelitian ini mengambil pada populasi, serta menggunakan instrumen kuisioner sebagai alat pengumpulan data. Analisis data yang digunakan dalam penelitian ini menggunakan analisis jalur (path analysis) yang bertujuan untuk mengetahui adanya pengaruh antar variabel sesuai dengan model kausalitas yang terbentuk. Dengan bantuan perhitungan melalui program SPSS. Menurut Ghozali (2005), Analisis jalur merupakan perluasan dari alat analisis regresi berganda, atau analysis path merupakan penggunaan regresi berganda untuk melihat hubungan sebab akibat antar variabel yang telah ditentukan berdasarkan tinjauan teoritis.

Penelitian ini diakukan pada pada Dinas Pendapatan Pengelolaan Keuangan dan Asset Kabupaten Malang, Jl. KH. Agus Salim No. 7 Malang dan UPTD Singosari Kabupaten Malang. Pengukuran variabel menggunakan skala likert. Sumber data diperoleh dari data primer dan data sekunder. Pengumpulan data dilakukan dengan kuesioner, dimana menggunakan instrumen pernyataan tertulis yang ditujukan kepada responden.

\section{Metode Pengumpulan Data}

Metode pengumpulan data dalam penelitian ini dengan menggunakan instrumen pernyataan tertulis yang ditujukan kepada responden, dan dirancang secara khusus untuk memperoleh informasi. Metode ini dilakukan dengan memberikan pertanyaan atau pernyataan terstruktur dan sistematis yang berkaitan dengan masalah pelatihan, disiplin kerja, komitmen organisasional dan kinerja yang diangkat dalam penelitian ini. Instrumen atau kuesioner yang telah dirancang sedemikian rupa tersebut akan diberikan secara langsung kepada responden pada DPPKA Kabupaten Malang.

Unit populasi pada DPPKA Kabupaten Malang sebesar 421 pegawai, dimana terdiri dari pegawai dengan status kepegawaian PNS maupun Tenaga Honorer/kontrak. Dalam menentukan jumlah sampel penelitian ini, peneliti menggunakan perhitungan statistik 
Yamane dalam Ferdinand (2006) dengan margin of error sebesar 5\%, dari perhitungan tersebut maka jumlah sampel sebanyak 205 orang. Teknik pengambilan sampel dalam penelitian ini menggunakan teknik proporsional random sampling dimana menurut Arikunto (2007) merupakan suatu teknik yang menunjuk pada ukuran besarnya bagian sampel dan penggunaanya selalu dikombinasikan dengan teknik-teknik sampling yang lain yang berhubungan dengan populasi yang tidak homogen.

\section{HASIL DAN PEMBAHASAN}

\section{Gambaran Umum Dinas Pendapatan Pengelolaan Keuangan dan Asset (DPPKA) Kabupaten Malang}

DPPKA (Dinas Pendapatan Pengelolaan Keuangan dan Asset) yang sebelumnya bernama BPKD (Badan Pengelolaan Keuangan Daerah) merupakan gabungan dari Dinas Pendapatan, Kantor Kas Daerah, Bagian Keuangan, dan Bagian Perlengkapan. Disini kenapa BPKD berubah nama menjadi DPPKA, karena pada saat itu BPKD mempunyai badan penggali tetapi kenyataannya sebagai Badan tidak diperbolehkan memiliki badan Penggali, sehingga seiring berjalannya waktu BPKD berubah menjadi Dinas dan berubah nama Menjadi DPPKA. Berdasarkan Peraturan Bupati Nomor 22 tahun 2008 tentang Organisasi Perangkat Daerah, DPPKA memiliki 1 Kepala Dinas yang dibantu oleh 1 Sekretaris Dinas dan 5 Kepala Bidang. Sekretaris sendiri dibantu oleh 3 Pejabat struktural (Kepala Sub Bagian), Begitu pula dengan Kepala Bidang. Tiap-tiap kepala Bidang dibantu oleh Kepala Seksi.

\section{Karakteristik Responden}

\section{Tabel 1. Karakteristik Responden} Berdasarkan Jenis Kelamin

\begin{tabular}{|l|c|c|}
\hline Jenis Kelamin & Frekuensi & Persentase \\
\hline Laki-Laki & 91 & $44.4 \%$ \\
\hline Perempuan & 114 & $55.6 \%$ \\
\hline
\end{tabular}

Sumber: data primer yang diolah tahun 2015

Berdasarkan jenis kelamin, sebagian besar pegawai Dinas Pendapatan Pengelolaan Keuangan dan Asset (DPPKA) Kabupaten
Malang yang telah berpartisipasi dalam penelitian ini adalah lebih banyak berjenis kelamin perempuan dimana prosentase sebesar $55.6 \%$, sedangkan yang berjenis laki-laki hanya memiliki prosentase sebesar $44.4 \%$, hal ini membuktikan bahwa sebagian besar populasi di DPPKA Kabupaten Malang lebih banyak berjenis kelamin perempuan.

\section{Tabel 2. Karakteristik Responden Berdasarkan Usia}

\begin{tabular}{|l|c|c|}
\hline Usia & Frekuensi & Persentase \\
\hline$\leq 25$ tahun & 52 & $25.4 \%$ \\
\hline $26-35$ tahun & 98 & $47.8 \%$ \\
\hline $36-45$ tahun & 33 & $16.1 \%$ \\
\hline$>45$ tahun & 22 & $10.7 \%$ \\
\hline
\end{tabular}

Sumber: data primer yang diolah tahun 2015

Berdasarkan usia, sebagian besar pegawai Dinas Pendapatan Pengelolaan Keuangan dan Asset (DPPKA) Kabupaten Malang yang telah berpartisipasi dalam penelitian ini adalah tertinggi di rentang usia 26 - 35 tahun dengan prosentase sebesar $47.8 \%$, sedangkan yang terendah adalah di rentang usia lebih dari 45 tahun dengan prosentase sebesar $10.7 \%$. Hal ini menjelaskan bahwa usia setiap orang sangat menentukan seberapa besar kemampuan yang di milikinya dalam merespon sesuatu. Karena di usia rentang 26-35 tahun pegawai sangat matang dalam berpikir dan memiliki rasa komitmen dalam organisasi tempat mereka bekerja.

Tabel 3. Karakteristik Responden Berdasarkan Pendidikan

\begin{tabular}{|l|c|c|}
\hline Pendidikan & Frekuensi & Persentase \\
\hline SMA/SMK & 83 & $40.5 \%$ \\
\hline D3 & 10 & $4.9 \%$ \\
\hline S1 & 107 & $52.2 \%$ \\
\hline S2 & 5 & $2.4 \%$ \\
\hline
\end{tabular}

Sumber: data primer yang diolah tahun 2015

Berdasarkan pendidikan, sebagian besar pegawai Dinas Pendapatan Pengelolaan Keuangan dan Asset (DPPKA) Kabupaten Malang yang telah berpartisipasi dalam penelitian ini berdasarkan background pendidikan adalah tertinggi dimana banyak pegawai yang berpendidikan S1 dengan prosentase sebesar $52.2 \%$, sedangkan yang 
terendah pegawai yang berpendidikan S2 dengan prosentase sebesar $2.4 \%$. Hal ini dapat menjelaskan bahwa tingkat pendidikan pegawai DPPKA Kabupaten Malang berada di level tinggi, karena diharapkan setiap pegawai mampu melaksanakan tugas dan kewajibannya sebagai pegawai pemerintahan yang baik karena dianggap memiliki keahlian dan kompetensi yang cukup.

\section{Tabel 4. Karakteristik Responden Berdasarkan Masa Kerja}

\begin{tabular}{|l|c|c|}
\hline Masa Kerja & Frekuensi & Persentase \\
\hline$\leq 5$ tahun & 133 & $64.9 \%$ \\
\hline $6-10$ tahun & 36 & $17.6 \%$ \\
\hline $11-20$ tahun & 22 & $10.7 \%$ \\
\hline $21-30$ tahun & 12 & $5.9 \%$ \\
\hline$>30$ tahun & 2 & $1.0 \%$ \\
\hline
\end{tabular}

Sumber: data primer yang diolah tahun 2015

Berdasarkan masa kerja, sebagian besar pegawai Dinas Pendapatan Pengelolaan Keuangan dan Asset (DPPKA) Kabupaten Malang yang telah berpartisipasi dalam penelitian ini, yang tertinggi dimana telah bekerja selama kurang dari sama dengan 5 tahun dengan prosentase sebesar $64.9 \%$, sedangkan yang terendah dimana pegawai tersebut telah bekerja lebih dari 30 tahun dengan prosentase sebesar $1.0 \%$. hal ini menunjukkan bahwa masa kerja pegawai menggambarkan bahwa responden yangada di masa kerja di bawah 5 tahun yang di dominasi tenaga honorer mempunyai semangat kerja yang tinggi dan sudah cukup mampu atau berpengalaman dalam melaksanakan pekerjaan.
Tabel 5. Karakteristik Responden Berdasarkan Status Kepegawaian

\begin{tabular}{|l|c|c|}
\hline Status Kepegawaian & Frekuensi & Persentase \\
\hline PNS & 60 & $29.3 \%$ \\
\hline Honorer & 145 & $70.7 \%$ \\
\hline
\end{tabular}

Sumber: data primer yang diolah tahun 2015

Berdasarkan status kepegawaian, sebagian besar pegawai Dinas Pendapatan Pengelolaan Keuangan dan Asset (DPPKA) Kabupaten Malang yang telah berpartisipasi dalam penelitian ini memiliki status kepegawaian yang terbesar adalah sebagai pegawai honorer dengan prosentase sebesar $70.7 \%$, sedangakn yang terkecil adalah pegawai dengan status kepegawaian sebagai Pegawai Negeri Sipil (PNS) dengan prosentase sebesar 29.3\%. Hal ini menunjukkan bahwa pegawai DPPKA Kabupaten Malang didominasi pegawai honorer karena luasnya wilayah kabupaten malang termasuk ke setiap kecamatannya yang memerlukan pengamatan lebih detail dan rinci dalam pengelolaannya, untuk itu diperlukan pegawai honorer dalam jumlah besar yang faktanya masih memiliki usia muda dan semangat kerja yang tinggi.

\section{Hasil Pengujian Hipotesis \\ Konversi Diagram Jalur ke dalam Model Pengukuran}

Konversi diagram jalur ke dalam model pengukuran dimaksudkan untuk mengetahui pengaruh antar variabel yang dijelaskan oleh efek pada model, yaitu efek langsung dan efek tidak langsung.

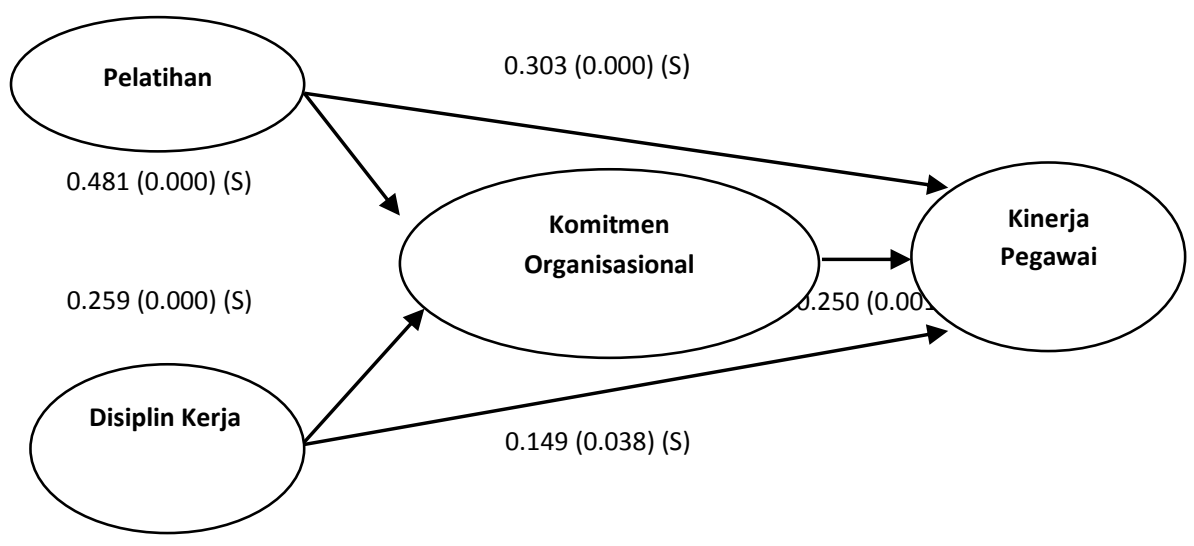


Gambar 1. Konversi Diagram Jalur (Path) ke dalam Model Pengukuran

Keterangan:

$(\mathrm{S})$ = Signifikan

$(\mathrm{TS})=$ Tidak Signifikan

Model empirik yang dihasilkan adalah sebagai berikut

Model 1: $\quad$ Komitmen $=0.481$ Pelatihan + 0.259 Disiplin Kerja

Model 2: $\quad$ Kinerja $=0.303$ Pelatihan +0.149 Disiplin Kerja + 0.250 Komitmen
Organisasional

Adapun pengaruh secara langsung maupun secara tidak langsung sebagaimana sebagi berikut:

\section{Tabel 6. Pengaruh Antar Variabel}

\begin{tabular}{|ccl|c|c|c|}
\hline \multicolumn{3}{|c|}{ Hubungan } & \multicolumn{3}{c|}{ Koefisien } \\
\cline { 4 - 7 } & & & Direct & Indirect & Total \\
\hline Pelatihan & $\rightarrow$ & Kinerja pegawai & $0.303^{*}$ & $0.120^{*}$ & 0.423 \\
\hline Disiplin kerja & $\rightarrow$ & Kinerja pegawai & $0.149^{*}$ & $0.065^{*}$ & 0.214 \\
\hline Pelatihan & $\rightarrow$ & Komitmen Org. & $0.481^{*}$ & - & 0.481 \\
\hline Disiplin kerja & $\rightarrow$ & Komitmen Org. & $0.259^{*}$ & - & 0.259 \\
\hline Komitmen Org. & $\rightarrow$ & Kinerja pegawai & $0.250^{*}$ & - & 0.250 \\
\hline
\end{tabular}

Sumber: data primer yang diolah Tahun 2015

Keterangan : * (significant)

Berdasarkan tabel dapat diketahui bahwa:

1. Pelatihan dapat meningkatkan kinerja pegawai sebesar 0.303 . Hal ini menunjukkan bahwa pelatihan berpengaruh terhadap kinerja pegawai. Dengan demikian semakin baik proses pelatihan maka cenderung dapat meningkatkan kinerja pegawai.

2. Disiplin kerja dapat meningkatkan kinerja pegawai sebesar 0.149. Hal ini menunjukkan bahwa disiplin kerja berpengaruh terhadap kinerja pegawai. Dengan demikian semakin tinggi disiplin kerja maka cenderung dapat meningkatkan kinerja pegawai.

3. Pelatihan dapat meningkatkan komitmen organisasional sebesar 0.481. Hal ini menunjukkan bahwa pelatihan berpengaruh positif terhadap komitmen organisasional. Dengan demikian semakin baik proses pelatihan maka cenderung dapat meningkatkan komitmen organisasional.

4. Disiplin kerja dapat meningkatkan komitmen organisasional sebesar 0.259 . Hal ini menunjukkan bahwa disiplin kerja berpengaruh terhadap komitmen organisasional. Dengan demikian semakin tinggi disiplin kerja maka cenderung dapat meningkatkan komitmen organisasional.
5. Komitmen organisasional dapat meningkatkan kinerja pegawai sebesar 0.250. Hal ini menunjukkan bahwa komitmen organisasional berpengaruh terhadap kinerja pegawai. Dengan demikian semakin tinggi komitmen organisasional maka cenderung dapat meningkatkan kinerja pegawai.

6. Peran komitmen organisasional dalam memediasi pengaruh pelatihan terhadap kinerja pegawai sebesar 0.120. Hal ini menunjukkan bahwa bahwa komitmen organisasional memiliki peran sebagai mediasi pengaruh pelatihan terhadap kinerja pegawai. Dengan demikian semakin tinggi komitmen organisasional yang disebabkan oleh semakin baiknya proses pelatihan maka cenderung dapat meningkatkan kinerja pegawai.

7. Peran komitmen organisasional dalam memediasi pengaruh disiplin kerja terhadap kinerja pegawai sebesar 0.065 . Hal ini menunjukkan bahwa komitmen organisasional memiliki peran sebagai mediasi pengaruh disiplin kerja terhadap kinerja pegawai. Dengan demikian, tinggi komitmen organisasional yang disebabkan oleh semakin tingginya disiplin kerja maka 
cenderung dapat meningkatkan kinerja pegawai.

Dalam hal ini juga dilakukan Pengujian positif parsial dimana pengujian ini digunakan untuk menguji hipotesis mengenai ada tidaknya pengaruh variabel independen secara parsial terhadap variabel dependen. Kriteria pengujian menyatakan bahwa apabila nilai probabilitas < level of significant $(\mathrm{alpha}=\alpha)$ maka dinyatakan adanya pengaruh variabel independen secara parsial terhadap variabel dependen. Pengujian positif parsial dapat diketahui melalui ringkasan pada tabel berikut:

Tabel 7. Pengujian Positif Parsial

\begin{tabular}{|ccc|c|c|c|}
\hline \multicolumn{2}{|c|}{ Hubungan } & Koef & t-statistics & Prob. \\
\hline Pelatihan & $\rightarrow$ & Kinerja pegawai & 0.303 & 3.908 & 0.000 \\
\hline Disiplin kerja & $\rightarrow$ & Kinerja pegawai & 0.149 & 2.091 & 0.038 \\
\hline Pelatihan & $\rightarrow$ & Komitmen Org. & 0.481 & 7.492 & 0.000 \\
\hline Disiplin kerja & $\rightarrow$ & Komitmen Org. & 0.259 & 4.038 & 0.000 \\
\hline Komitmen Org, & $\rightarrow$ & Kinerja pegawai & 0.250 & 3.323 & 0.001 \\
\hline
\end{tabular}

Sumber: data primer yang diolah Tahun 2015

\section{Hipotesis 1. Pelatihan berpengaruh positif terhadap Kinerja Pegawai}

Pengaruh pelatihan terhadap kinerja pegawai menghasilkan nilai t-statistics sebesar 3.908 dengan probabilitas sebesar 0.000. Hasil pengujian tersebut menunjukkan bahwa probabilitas < alpha (5\%). Hal ini berarti terdapat pengaruh positif secara langsung pelatihan terhadap kinerja pegawai. Dengan demikian hipotesis 1 terpenuhi.

Hasil penelitian secara empiris sejalan dengan penelitian yang dilakukan oleh Iqbal et al. (2014), hasil penelitian menunjukkan hubungan positif antara Pelatihan, Gaji dan Keterlibatan Kerja dengan Kinerja Pegawai. Selain itu menurut, Agusta dan Sutanto (2013), hasil dari penelitiannya juga menunjukan bahwa pelatihan berpengaruh positif dan signifikan terhadap kinerja pegawai.

\section{Hipotesis 2. Disiplin Kerja berpengaruh positif terhadap Kinerja Pegawai}

Pengaruh disiplin kerja terhadap kinerja pegawai menghasilkan nilai $t$ statistics sebesar 2.091 dengan probabilitas sebesar 0.038. Hasil pengujian tersebut menunjukkan bahwa probabilitas < alpha (5\%). Hal ini berarti terdapat pengaruh positif secara langsung disiplin kerja terhadap kinerja pegawai. Dengan demikian hipotesis 2 terpenuhi.

Hasil penelitian ini secara empiris sejalan dengan penelitian Maharani dan Rahmawati (2010), dijelaskan Penerapan disiplin kerja berupa disiplin preventif dan disiplin korektif memiliki pengaruh terhadap prestasi kerja pegawai. Disiplin preventif memiliki pengaruh nyata terhadap prestasi kerja.

\section{Hipotesis 3. Pelatihan berpengaruh positif terhadap Komitmen Organisasional}

Pengaruh pelatihan terhadap komitmen organisasional menghasilkan nilai $\mathrm{t}$ statistics sebesar 7.492 dengan probabilitas sebesar 0.000 . Hasil pengujian tersebut menunjukkan bahwa probabilitas < alpha (5\%). Hal ini berarti terdapat pengaruh positif secara langsung pelatihan terhadap komitmen organisasional. Dengan demikian hipotesis 3 terpenuhi.

Hasil penelitian secara empiris sejalan dengan penelitian yang dilakukan oleh Chaudhuri (2012), dijelaskan bahwa ada hubungan positif yang ditemukan antara pelatihan outsourcing dan komitmen organisasional. Selain itu juga dalam penelitian Bartlett and Dae-seok Kang (2004), yang menunjukkan hasil penelitian dimana indikatorindikator dari variabel pelatihan seperti akses dalam pelatihan, frekuensi pelatihan, motivasi untuk belajar dari pelatihan, manfaat pelatihan, dan dukungan pengawasan untuk pelatihan memiliki pengaruh positif terkait dengan komponen afektif dan normatif komitmen.

Hipotesis 4. Disiplin Kerja berpengaruh positif terhadap Komitmen Organisasional 
Pengaruh disiplin kerja terhadap komitmen organisasional menghasilkan nilai $\mathrm{t}$ statistics sebesar 4.038 dengan probabilitas sebesar 0.000 . Hasil pengujian tersebut menunjukkan bahwa probabilitas < alpha (5\%). Hal ini berarti terdapat pengaruh positif secara langsung disiplin kerja terhadap komitmen organisasional. Dengan demikian hipotesis 4 terpenuhi. Secara empiris hasil penelitian ini sejalan dengan penelitian yang dilakukan oleh Widjaya (2008), dijelaskan bahwa Komitmen organisasional berpengaruh terhadap disiplin kerja pegawai.

\section{Hipotesis 5. Komitmen Organisasional positif memediasi pengaruh Pelatihan terhadap Kinerja Pegawai}

Peran komitmen organisasional dalam memediasi pengaruh pelatihan terhadap kinerja pegawai diketahui dimana melihat hasil pengujian dari pelatihan yang berpengaruh positif terhadap komitmen organisasional dan komitmen organisasional yang juga berpengaruh positif terhadap kinerja pegawai. Oleh karena kedua jalur tersebut dinyatakan positif maka dapat dinyatakan terdapat peran yang positif juga dimana ada komitmen organisasional yang memiliki peran positif dalam memediasi pengaruh pelatihan terhadap kinerja pegawai. Dengan demikian komitmen organisasional dikatakan mampu memediasi pengaruh pelatihan terhadap kinerja pegawai dengan baik, sehingga hipotesis 5 terpenuhi

\section{Hipotesis 6. Komitmen Organisasional positif memediasi pengaruh Disiplin Kerja terhadap Kinerja Pegawai}

Peran komitmen organisasional dalam memediasi pengaruh disiplin kerja terhadap kinerja pegawai diketahui dimana melihat hasil pengujian dari disiplin kerja yang berpengaruh positif terhadap komitmen organisasional dan komitmen organisasional yang juga berpengaruh positif terhadap kinerja pegawai. Oleh karena kedua jalur tersebut dinyatakan positif maka dapat dinyatakan terdapat peran yang positif juga dimana ada komitmen organisasional yang memiliki peran positif dalam memediasi pengaruh disiplin kerja terhadap kinerja pegawai. Dengan demikian komitmen organisasional dikatakan mampu memediasi pengaruh disiplin kerja terhadap kinerja pegawai dengan baik, sehingga hipotesis 6 terpenuhi.

\section{Implikasi Penelitian}

Implikasi praktis dalam penelitian adalah bahwa setiap organisasi maupun instansi pemerintahan tentunya memiliki strategi untuk meningkatkan komitmen maupun kinerja dari setiap pegawainya, sehingga dengan mengacu pada hasil dari penelitian ini pimpinan maupun pihak yang terkait dalam DPPKA Kabupaten Malang harus terus berupaya atau mendorong agar setiap pegawai termotivasi untuk meningkatkan, dan membangun komitmen organisasional pada dirinya dan terus belajar untuk meningkatkan soft skills dalam diri masing-masing.

\section{Keterbatasan Penelitian}

Penelitian ini masih memiliki beberapa keterbatasan, sebagai berikut: Karakteristik responden dimasing-masing daerah dan organisasi pemerintahan pasti berbeda, tergantung dari lingkungan dan budaya setempat, sehingga hasil penelitian ini tidak bisa digeneralisir untuk organisasi pemerintahaan yang memiliki kesamaan nama di daerah yang lain, dan Ciri karakteristik pada setiap daerah sudah tentu berbeda, sehingga hasil penelitian ini tidak dapat digeneralisasi untuk pemerintah daerah lain dengan karakteristik serta kondisi yang sama. Hal ini perlu digaris bawahi mengingat dalam suatu organisasi atau daerah pastinya memiliki budaya yang multikultural.

\section{KESIMPULAN}

Berdasarkan tujuan dan hasil dalam pembahasan penelitian ini, maka diambil kesimpulan bahwa komitmen organisasional memiliki peran positif dalam memediasi pengaruh pelatihan dan disiplin kerja terhadap kinerja pegawai DPPKA Kabupaten Malang, dimana komitmen organisasional dalam hal ini berperan sebagai variabel mediasi. Tetapi dalam hasil penelitian ini pengaruh mediasi dari komitmen organisasional merupakan mediasi secara parsial (partially mediated), sehingga ke depan diharapkan DPPKA terus dapat lebih fokus dalam peningkatan komitmen dan kinerja dari setiap pegawainya.

Oleh karena itu, berdasarkan tujuan dan hasil penelitian maka dapat diambil saran 
bahwa DPPKA Kabupaten Malang harus terus berupaya atau mendorong agar setiap pegawai termotivasi untuk meningkatkan, dan membangun komitmen organisasional pada dirinya dan terus belajar untuk meningkatkan soft skills dalam diri masing-masing. Karena apabila strategi dalam peningkatan komitmen pegawai ini berjalan dengan baik maka tingkatan komitmen dari setiap pegawaipun akan menjadi semakin tinggi, sehingga dalam hal ini mampu meningkatkan kinerja dan standart kerja dari setiap pegawai dalam DPPKA Kabupaten Malang.

\section{DAFTAR PUSTAKA}

Agusta, Leonando Dan Eddy Madiono Sutanto. 2013. Pengaruh Pelatihan dan Motivasi Kerja terhadap Kinerja Pegawai CV Haragon Surabaya. AGORA, Vol. 1, No. 3,2013

Arikunto, Suharsimi. 2007. Manajemen penelitian. Jakarta : Rineka Cipta.

Bartlett, Kenneth and Dae-seok Kang. 2004. Training and Organizational Commitment among Nurses in New Zealand and United States Public Hospitals Experiencing Industry and Organizational Change. Paper presented at the Academy of Human Resource Development International Conference (AHRD) (Austin, TX, Mar 37, 2004) p383-390 (Symp. 19-2)

Chaudhuri, Sanghamitra. 2012. The Relationship Between Training Outsourcing and Organizational
Commitment. Human resource development international : enhancing performance, learning and integrity, Vol. 17.2014, 2, p. 145-163

Ferdinand, Augusty. 2006. Metode Penelitian Manajemen. Edisi Kedua. Universitas Diponegoro. Semarang.

Ghozali, Imam. (2005). "Aplikasi Analisis Multivariate Dengan Program SPSS". Semarang : Badan Penerbit Undip.

Hasibuan, Malayu. (2009). Manajemen Sumber Daya Manusia, Edisi Revisi, Bumi Aksara, Jakarta.

Iqbal, Nadeem, Naveed Ahmad, And Komal Javaid. 2014. Impact of Training on Employee Performance In The Context of Telecommunication Sector Of D. G. Khan, (Pakistan). International Letters of Social And Humanistic Sciences 6 (2014) 60-73

Luthans, Fred. (2006). Perilaku Organisasi Edisi sepuluh. Yogyakarta: Penerbit ANDI.

Maharani, Intan Ratna dan Siti Rahmawati. 2010. Pengaruh Penerapan Disiplin Kerja Terhadap Prestasi Kerja Pegawai Dinas Pendidikan Kabupaten Ciamis . Jurnal Manajemen dan Organisasi Vol I, No. 3, Desember 2010

Sutrisno, Edy. (2012). Manajemen Sumber Daya Manusia, Kencana, Jakarta

Widjaya, Christian. 2008. Analisis Pengaruh Komitmen Organisasional dan Kepuasan Kerja terhadap Disiplin Kerja Pegawai PT. Leo Agung Raya Semarang. 